Original Research

\title{
Zinc oxide nanoparticles promote the aging process in a size-dependent manner
}

\author{
Mahla Deylam $^{1} \cdot$ Effat Alizadeh $^{2} \cdot$ Manizheh Sarikhani $^{1} \cdot$ Marzie Hejazy $^{3} \cdot{\text { Masoumeh Firouzamandi }{ }^{1}}^{1}$
}

Received: 16 May 2021 / Accepted: 5 September 2021 / Published online: 30 September 2021

(c) The Author(s) 2021

\begin{abstract}
Zinc oxide (ZnO) nanoparticles (NPs) are generally utilized in cosmetic goods, sheds, biosensors, and delivery of drug. As in vitro ideal systems, mesenchymal stem cells (MSCs) are used to test acute toxicity. In the present study, size-dependent cytotoxicity effects of ZnO NPs on MSCs were assessed. Bone marrow and adipose MSCs were treated with ZnO NPs with average sizes of $10-30$ and $35-45 \mathrm{~nm}$. The 5 and $10 \mu \mathrm{g} / \mathrm{ml}$ concentrations of $\mathrm{ZnO}$ NP were found to be the safe concentrations for the NP sizes of 10-30 and 35-45 nm, respectively. Cell-cycle analysis indicated that the small size of ZnO NPs has more negative effects on the process of cell entry to DNA synthesis when compared to the larger size. The results of the $\beta$-galactosidase test showed the promotion of the aging process in the cells treated with the smaller size of ZnO NPs. Both sizes of the NP were found to upregulate the aging-related genes NF-kB and p53 and downregulate the anti-aging gene Nanog. To sum up, the smaller size of ZnO NPs can enhance the aging process in the cells.
\end{abstract}

\section{Graphical Abstract}

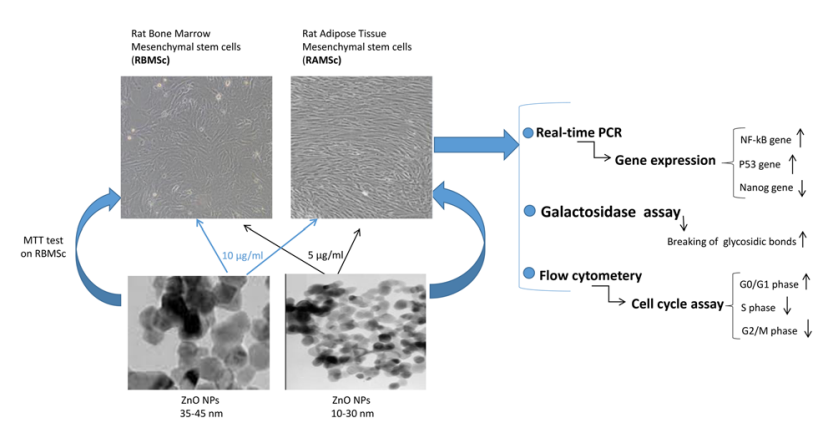

\section{Introduction}

Masoumeh Firouzamandi

m.firouzamandi@tabrizu.ac.ir

1 Department of Pathobiology, Faculty of Veterinary Medicine, University of Tabriz, Tabriz, Iran

2 Department of Medical Biotechnology, Faculty of Advanced Medical Sciences, Tabriz University of Medical Sciences, Tabriz, Iran

3 Department of Basic Science, Faculty of Veterinary Medicine, University of Tabriz, Tabriz, Iran
In the recent decade, the nanotechnology industry needs to be developed quickly around the world. Zinc oxide ( $\mathrm{ZnO})$ nanoparticles (NPs) are generally utilized in beauty care products, sheds, biosensors, drug delivery, bioimaging, and as antifungal and antibacterial agents [1-5]. $\mathrm{ZnO}$ nanostructures have a few excellent properties as well as compound stability, great specific surface range, high electron correspondence highlights, and electro compound activity [6]. ZnO NPs are for the most part used as a UV light dissipating added substance in cosmetic products such as sunscreens, toothpastes, and magnificence products [7, 8]. With the widespread application of nano-structured substances for commercial items, the biosafety of these materials has been considered to explore the natural and toxicological effects of aberrant and immediate 
manifestation of these substances [9]. Owing to their reactive oxygen species (ROS) and insoluble metal ions, nanomaterials such as $\mathrm{ZnO}$ have toxic impacts on the cells $[10,11]$. As the toxicity of $\mathrm{ZnO}$ NPs is higher in ultrapure water than in phosphate-buffered saline (PBS) in various aqueous media, the toxicity of ZnO NPs is mostly in line for the free zinc ions [12]. While zinc NP complex with media and cause lower toxicity, the concentration of $\mathrm{Zn}^{2+}$ ions is greatly reduced. The generated $\mathrm{Zn}^{2+}$ insoluble $\mathrm{ZnO}$ NPs induce necrosis and inflammation [13]. Intercellular ROS, which is caused by ZnO NPs, induces cell death and dysfunction of mitochondrial oxidative phosphorylation [10].

Several in vivo experiments have indicated the harmful effects of Zn NPs on various life forms such as drosophila [14], fish [15], amphipods [16], mice [17], rats [18], and bacteria [19]. Zn NPs have also been reported to show in vitro toxicity [20-22]. Despite many hidden toxicities associated with $\mathrm{ZnO}$ NPs, they are widely used for various biomedical applications and pharmaceutical purposes [23]. Hence, further research is needed to evaluate the toxic impact of this compound on the cells. In toxicology research, MSCs are utilized as an ideal in vivo modeling [24]. Isolation and extension of MSCs in culture is easy, and their differentiation is done through proper stimulation. Bone marrow mesenchymal stem cells (BMSCs) show sensitivity to cytotoxicity tests of cancer medicines and some other cytotoxic medications [25]. Moreover, adiposederived mesenchymal stem cells (AMSCs) are utilized to assess drug safety and to discover medications [26]. Therefore, in this study, we supposed that AMSCs and BMSCs targeted by $\mathrm{ZnO}$ NPs might be suitable for considering the potential risks in the aging development. To evaluate cell toxicity, gene expression assay, a factor that plays a role in early toxic processes, is highly significant [26]. Thus, as a specific stem cell marker, Nanog gene was utilized in the present research to anticipate toxicity. Nanog has two functions in stem cell differentiation and self-renewal [27]. Moreover, Nanog gene stimulates the senescence suppression by downregulating the expression of $\mathrm{p} 27^{\mathrm{KIP} 1}$ gene [28]. In classic response to genotoxicity, to restrict cell proliferation, p53 in the corrupted genomes causes the cellcycle arrest and cell death. Numerous investigations have highlighted the role of NF-kB framework in activating the stimulating changes in tissues during aging [29]. Therefore, in the present study, cell-cycle assay, galactosidase in situ assay, and mRNA levels of NF-kB, p53, and Nanog genes were considered.

\section{Materials and methods}

\subsection{Properties and characterization of nanoparticles}

Two different sizes of ZnO NPs (Sigma Aldrich, USA) with the following information were purchased: one with
$10-30 \mathrm{~nm}$ average size, $+99 \%$ purity, $5.606 \mathrm{~g} / \mathrm{cm}^{3}$ density, and about $20-60 \mathrm{~m}^{2} / \mathrm{g}$ surface area, and the other with $35-45 \mathrm{~nm}$ average size, $+99 \%$ purity, $5.606 \mathrm{~g} / \mathrm{cm}^{3}$ density, and about $65 \mathrm{~m}^{2} / \mathrm{g}$ surface area (Fig. 1). Then, a stock of $100 \mu \mathrm{g} / \mathrm{ml}$ of $\mathrm{ZnO}$ NPs suspension in $1 \mathrm{ml}$ of PBS was prepared by sonication for $3 \mathrm{~min}$.

\subsection{Isolation of mesenchymal stem cells}

BMSCs were picked from 8-week-old (200-250 g) male rats. The epiphyses were removed, the marrow cavities were accessed, and total bone marrow (BM) plugs were blushed out of tibial and femoral bones by a $10 \mathrm{ml}$ syringe containing Dulbecco's modified eagle medium (DMEM) (Laboratories Inc., MA, USA) plus 10\% fetal bovine serum (FBS). BM samples were gathered and precisely upset by successive desire needles of 18 and 20 gauge appended to a similar $10 \mathrm{ml}$ syringe. Then, the cell suspension was centrifuged for $5 \mathrm{~min}$ at $1000 \mathrm{rpm}$. After pelleting the cells, they were resuspended in the medium with $10 \%$ FBS. To play out a cell tally counter, $4 \%$ acetic acid was mixed with a low amount of the suspension to lyse the red blood cells. Counting of the cells was done by hemocytometer. Subsequently, the $5 \times 10^{7}$ cells cells were plated in $100 \mathrm{~mm}$ culture dish, kept in $5 \% \mathrm{CO}_{2}$ at $37^{\circ} \mathrm{C}$, and changed with a fresh medium each 3-4 days [30]. Using collagenase type I $\left(0.15 \%\right.$ weight to volume) for $1 \mathrm{~h}$ at $37^{\circ} \mathrm{C}$, the adipose tissue was then enzymatically separated. To remove undissociated particles, the suspension was filtered with a $70-\mu \mathrm{m}$ filter. Then, DMEM with $10 \%$ (v/v) FBS was added and centrifuged at $700 \times \mathrm{g}$ for $5 \mathrm{~min}$. Finally, the pellet of the cell was resuspended in DMEM with $1 \%(\mathrm{v} / \mathrm{v})$ penicillin/streptomycin and 10\% (v/v) FBS [31].

\subsection{Cell culture}

AMSCs and BMSCs were cultured in DMEM (Laboratories Inc., MA, USA) with $1 \%$ antibiotics and $10 \%$ FBS in the standard culture conditions (at $37{ }^{\circ} \mathrm{C}$, in $5 \% \mathrm{CO}_{2}$, and $95 \%$ humidity) [32].

\subsection{Characterization of surface markers of BMSCs and AMSCs}

BMSCs and AMSCs were harvested for $5 \mathrm{~min}$ at $37^{\circ} \mathrm{C}$, plated by $200 \times$ g centrifugation for $5 \mathrm{~min}$, and rinsed with chilled PBS. Next, $5 \mu \mathrm{l}$ of fluorescein isothiocyanat (FITC)conjugated antibodies, including CD34-PE, CD90-FITC, CD45-FITC, and CD73-FITC (Thermo Fisher Scientific, Germany), was added to the BMSCs and AMSCs and then stored at room temperature (RT) and a dark place for $20 \mathrm{~min}$. The samples were evaluated with a flow cytometer (BD FACS Caliber; San Jose, CA, USA) [33, 34]. 
Fig. 1 SEM images of $\mathrm{ZnO}$ nanoparticles. a ZnO NPs in $1 \mu \mathrm{m}$ scale, b $\mathrm{ZnO}$ NPs in $200 \mathrm{~nm}$ scale, $\mathbf{c}$ size of $10-30$ $\mathrm{ZnO}$ NPs in $200 \mathrm{~nm}$ scale, $\mathbf{d}$ size of 35-45 ZnO NPs in $200 \mathrm{~nm}$ scale
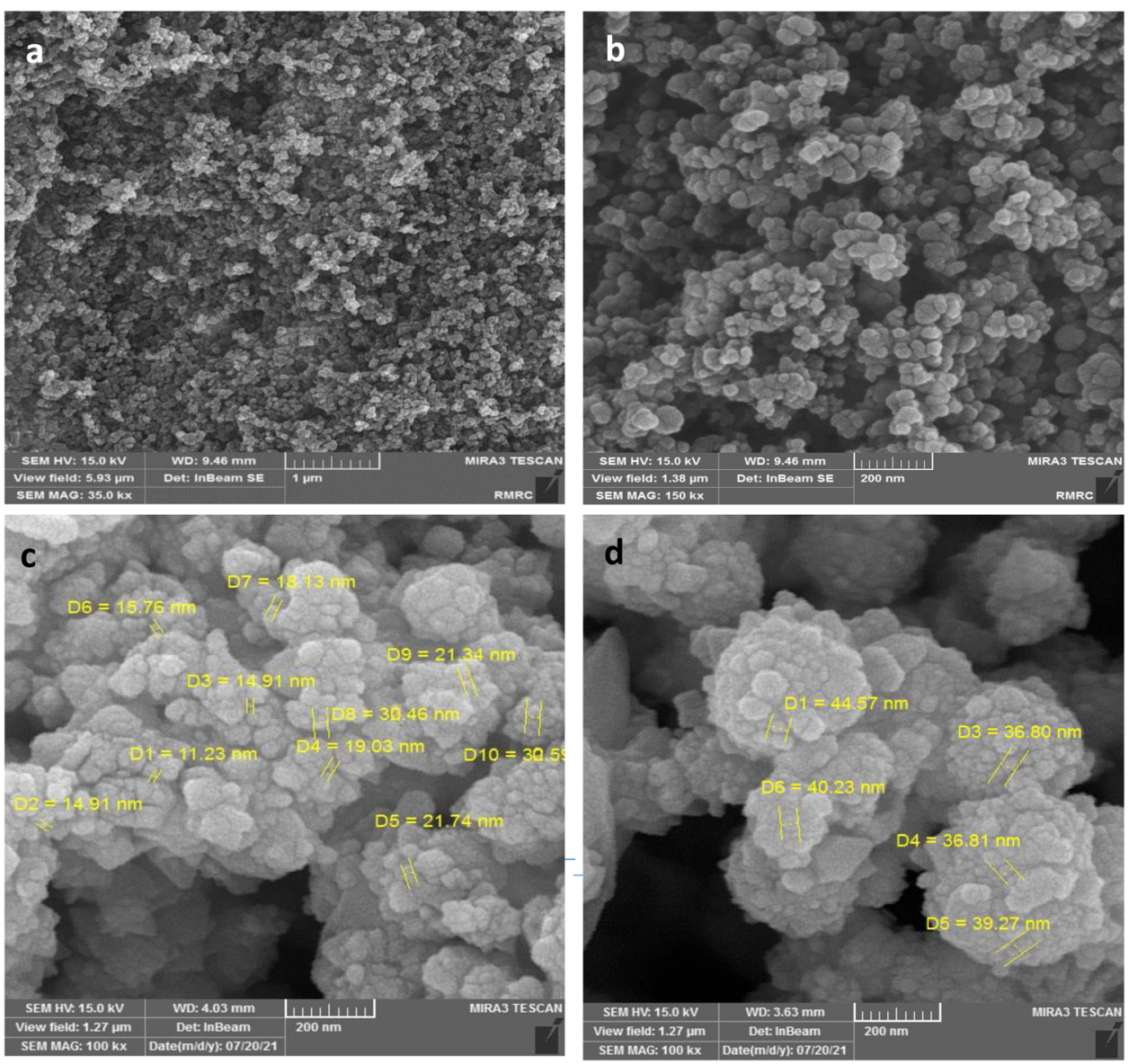

\subsection{In vitro cytotoxicity}

For cytotoxicity testing of NPs, the BMSCs and AMSCs were culture into 96-well plates at confluency of $70-80 \%$, all particles were suspended in complete DMEM (10\% diluted NPs with 90\% DMEM containing PBS) [35]. Bath sonication was done twice, each time for $5 \mathrm{~min}$, to finely mix the final $\mathrm{ZnO}$ NPs concentrations. Therefore, the BMSCs and AMSCs were treated with different concentrations $(0,3,5,10,25$, and $50 \mu \mathrm{g} / \mathrm{ml})$ of $\mathrm{ZnO}$ NPs for 24,48 , and $72 \mathrm{~h}$. Then, MTT assay was used to test the viability of the treated cells. Preparation of MTT stock solution ((3-(4,5-diminish ethylthiazol-2yl)- 2,5-diphenyltetrazolium bromide) was done by adding $1 \mathrm{ml}$ PBS to $5 \mathrm{mg}$ MTT (Sigma, USA) in a dark place. Then, $20 \mu \mathrm{l}$ of the stock solution was mixed with all experimental wells (control cells and $\mathrm{ZnO}$ NPs treated with different concentrations), vibrated for $10 \mathrm{~min}$, and incubated at $37^{\circ} \mathrm{C}$ for $3 \mathrm{~h}$. Lastly, the samples were ousted from the incubator and mixed with DMSO, with a purple color noticeable at this stage. They were developed over pipetting and read immediately in the presence of UV at $570 \mathrm{~nm}$.

\subsection{Cell-cycle assay}

BMSCs and AMSCs were seeded in different 6-well plates. While the $70 \%$ cell confluence was observed, safe ZnO NPs concentrations ( 5 and $10 \mu \mathrm{g} / \mathrm{ml}$ in smaller and larger sizes of $\mathrm{ZnO}$ NPs were obtained, respectively) were treated on the cells for MTT assay and incubated for $72 \mathrm{~h}$ at $37^{\circ} \mathrm{C}(5 \%$ $\mathrm{CO}_{2}$ ). The media were removed from the confocal disk after $72 \mathrm{~h}$ and were washed with PBS twice and centrifuged. The cells were fixed using ethanol (70\%) at $4{ }^{\circ} \mathrm{C}$ for 2 days. Then, the incubated cells were again rinsed with PBS and slightly shaken, following which the media were completely removed from the confocal disk. Next, $10 \mu \mathrm{R}$ Rase was added and incubated for $45 \mathrm{~min}$. For staining, the cells were suspended with $10 \mu$ propidium iodide solution (Sigma, USA). A flow cytometer was sued to evaluate the DNA of cells [36].

\subsection{Galactosidase in situ assay for cellular senescence}

The activity of senescence-associated-galactosidase (SA-gal), as a common biomarker for aging assay in the cells, was assessed by SA- $\beta$-gal staining kit (Thermo Fisher Scientific, 
Germany) the same as previous studies [37]. Cells were seeded in 24-well plates and treated with two different sizes of $\mathrm{ZnO}$ NPs with safe concentrations. Next, they were washed in PBS, fixed in G/F fixative mix (20\% glutaraldehyde $+37 \%$ formaldyde), and incubated at RT for 3-5 min. Then, the cells were then stained in a fresh staining solution $(10 \mathrm{ml}$ citrate $\mathrm{Na}+250 \mu \mathrm{l}$ potassium ferricyanide $+250 \mu$ l potassium ferrocyanide $+100 \mu \mathrm{l} \mathrm{MgCl}+250 \mu \mathrm{l} \mathrm{NaCl}+200 \mu \mathrm{l}$ X-gal) for $2 \mathrm{~h}$ in a dark place at $37^{\circ} \mathrm{C}$. SA- $\beta$-gal-positive cells exhibiting green color were visualized using an inverted light microscope.

\subsection{Real-time PCR}

The BMSCs and AMSCs with two different sizes of $\mathrm{ZnO}$ NPs were treated in 5 and $10 \mu \mathrm{g} / \mathrm{ml}$ optimum concentrations, respectively. They were harvested after $48 \mathrm{~h}$, and RNA extraction kit (Bio Basic INC) was used to extract total RNA. The first strand of cDNA was synthesized by reverse transcription using SYBR Green qPCR MasterMix 2X kit, SYBR $^{\circ}$ Premix Ex Taq ${ }^{\mathrm{TM}}$ (TaKaRa, Japan). Then, the quality and quantity of the synthesized cDNA was evaluated by a NanoDrop ND-1000 spectrophotometer (Thermo Scientific, Germany). Then, $2 \mu \mathrm{l}$ of the cDNA was used for target gene amplification. Specific primers were designed by the Primer 3 software and used to amplify the expression of p53, NF-kB, and Nanog genes (Generay Biotech, Korea). The sequencing of primers is presented in Table 1.

The expression levels were normalized to the expression level of the GAPDH gene as a housekeeping gene. To perform real-time PCR, the first cycle at $95^{\circ} \mathrm{C}$ for $3 \mathrm{~min}$ and 40 cycles at $95^{\circ} \mathrm{C}$ for $20 \mathrm{~s}$, at $60^{\circ} \mathrm{C}$ for $20 \mathrm{~s}$, and at $72{ }^{\circ} \mathrm{C}$ for $30 \mathrm{~s}$ were used.

\subsection{Statistical analysis}

All the tests were performed in triplicate, and the results were displayed as mean \pm standard deviation (SD). The data were fed into SPSS (IBM Corp. NY, USA) software and analyzed by two-way analysis of variance (ANOVA).

\section{Results}

\subsection{Flow cytometry analysis of mesenchymal stem cells}

Rat mesenchymal stem cells were separated from two origins, including adipose tissue and BM. The surface CD markers of MSCs were checked, and a majority of AMSCs or BMSCs (98.18 and 99.62\%) were found for CD90 as a positive surface marker in MSCs (Fig. 2A, B). Furthermore, 94.80 and 99.76\% of CD73 in AMSCs or BMSCs were definitely stained, respectively (Fig. 2A, B). Moreover, an ignoble percentage of BMSCs or AMSCs showed the expression of CD45 (0.18 or $0.56 \%$ ) and CD34 (0.71 or 12.65\%) in AMSCs or BMSCs, respectively, which are the markers of hematopoietic lineages (Fig. 2A, B). These molecular profiles demonstrate the extraordinary properties of the BMSCs and AMSCs. Furthermore, they approve of the quality removal of hematopoietic cells and isolation of mesenchymal stem cells from adipose tissue and $\mathrm{BM}$ during the isolation of stromal cells.

\subsection{In vitro cytotoxicity}

The MTT-based colorimetric cytotoxicity test was applied to investigate the viability of BMSCs or AMSCs following their treatments with $10-30$ and $35-45 \mathrm{~nm} \mathrm{ZnO} \mathrm{NPs} \mathrm{for} \mathrm{1,} \mathrm{2,} \mathrm{and}$ 3 days (Fig. 3). According to the data shown in Fig. 2, the effects of two different $\mathrm{ZnO}$ NPs sizes on BMSCs or AMSCs were dependent on dose and time. At dose 5 and $10 \mu \mathrm{g} / \mathrm{ml}$, 10-30 and 35-45 $\mathrm{nm}$ ZnO NPs indicated good viability for the AMSCs and BMSCs, respectively (Fig. 3). Furthermore, the viability of AMSCs and BMSCs with 35-45 nm ZnO NPs was decreased in a dose- and time-dependent manner at the same concentrations (Fig. 3).

\subsection{Cell-cycle assay}

The effects of $\mathrm{ZnO}$ NPs on the cell-cycle distributions of BMSCs and AMSCs were studied using propidium iodide staining and measured by flow cytometry. As shown in Fig. 4, the AMSCs and BMSCs treated with $10-30 \mathrm{~nm} \mathrm{ZnO}$ NPs
Table 1 Sequences of primers for real-time PCR analysis of mRNAs

\begin{tabular}{llll}
\hline Gene & Primers & Sequence $\left(5^{\prime} \rightarrow 3^{\prime}\right)$ & Accession number \\
\hline Nanog & F: & GAGACTGCCTCTCCTCCGCCTT & AB275459.1 \\
& R: & GTGCACACAACTGGGCCTGA & \\
P53 & F: & GTCGGCTCCGACTATACCACTATC & NM_030989.3 \\
& R: & CTCTCTTTGCACTCCCTGGGG & \\
NF-kB & F: & TTCCCTGAAGTGGAGCTAGGA & NM_199267.2 \\
& R: & CATGTCGAGGAAGACACTGGA & \\
GAPDH & F: & TCAAGAAGGTGGTGAAGCAG & NM_017008.4 \\
& R: & AGGTGGAAGAATGGGAGTTG & \\
\hline
\end{tabular}



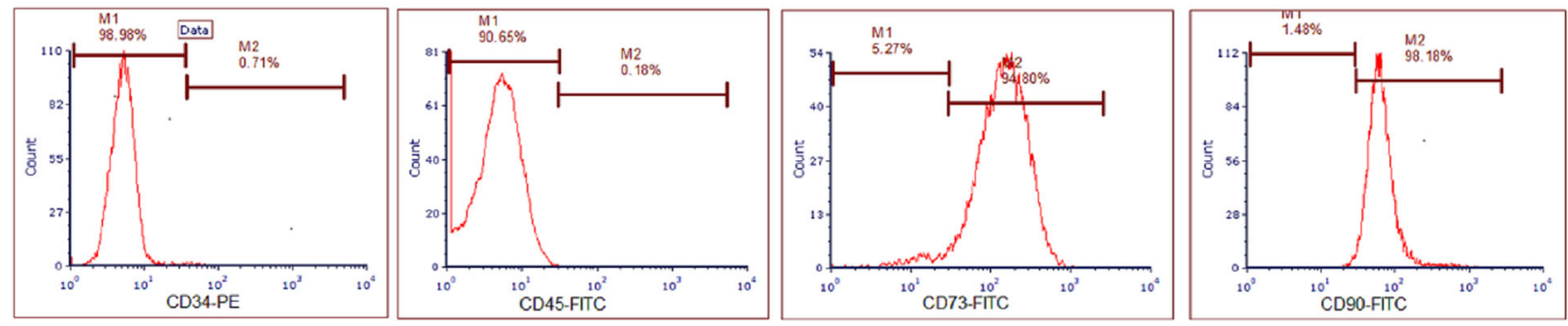

A: Characterization of typical stem cell on RAMSCs
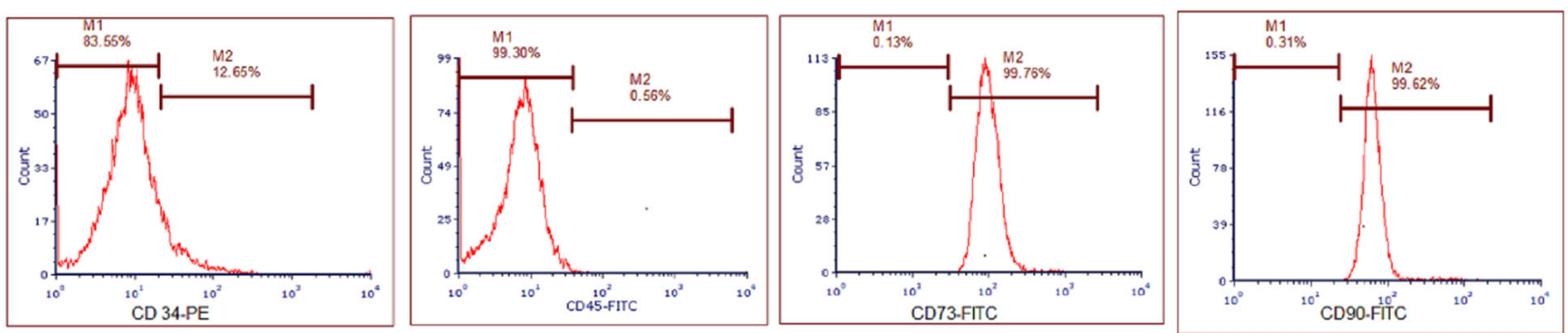

B: Characterization of typical stem cell on RBMSCs

Fig. 2 Characterization of the typical stem cell (AMSCs and BMSCs) surface markers CD31, CD34, CD73, and CD90 using flow cytometry. A Hematopoietic progenitor cell marker CD34 and pan-leucocyte marker CD45 in BMSCs are ignorable percentages in BMSCs. Surface markers CD73 and CD90 are used as positive markers to identify

BMSCs. B Hematopoietic progenitor cell marker CD34 and CD45 are low in AMSCs. Surface marker CD90 and CD73 are used as positive markers to identify AMSCs. The $y$-axis represents the cell number and the $x$-axis shows the fluorescence intensity
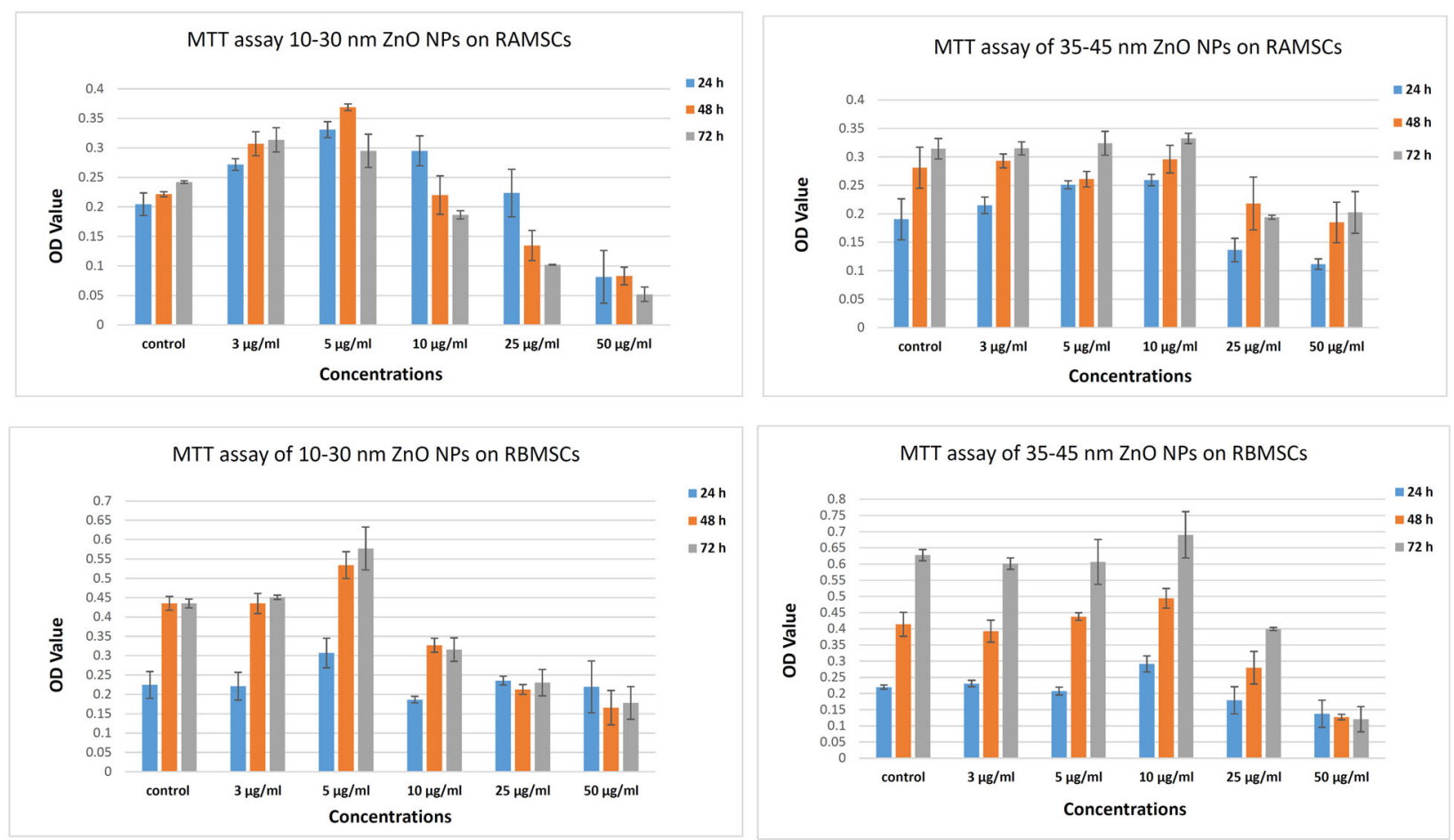

Fig. 3 Effects of ZnO NPs on the viability of AMSCs and BMSCs, determined by MTT assay after 1, 2, and 3 days incubation with 10-30 and 35-45 ZnO NPs in comparison to the control group. Optimum OD of cells treated with 10-30 ZnO NPs was obtained at

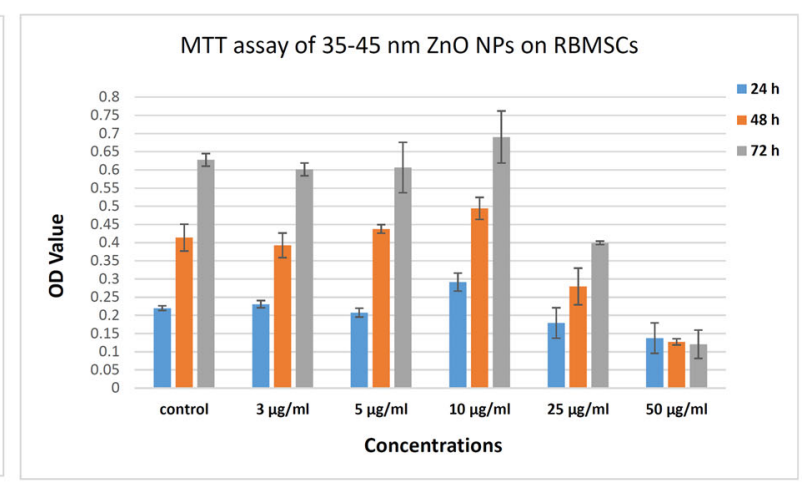

$5 \mu \mathrm{g} / \mathrm{ml}$ concentration, and optimum OD of cells treated with $35-45$ $\mathrm{ZnO}$ NPs was obtained at $10 \mu \mathrm{g} / \mathrm{ml}$ concentration. The error bars show mean $\pm \mathrm{SD}$ 
indicated that the ratio of cells entering G0/G1 phase increased (82.2 and $82.01 \%$ ) compared to the control group (81.92 and $78.76 \%$, respectively). When signals driving proliferation experience apoptosis or are missing, cells have a tendency to increase in G0/G1 [38].

Moreover, in the AMSCs and BMSCs treated with 10-30 $\mathrm{nm} \mathrm{ZnO}$ NPs, the G2/M phase decreased (7.38 and 9.98\% receptively) compared to the control group (10.04 and $13.47 \%$ ), indicating that the cells were arrested at $\mathrm{S}$ cell-cycle and G2/M phases and were not actively proliferating (Fig. 4). However, cell-cycle analysis of 35-45 nm ZnO NPs indicated an increased accumulation of G2/M phase cells in AMSCs and BMSCs (14.19 and $16.18 \%$, receptively) in comparison to the control group G2/M (10.04 and 13.47\%), indicating the retardation of cell-cycle process (Fig. 4). When DNA is harmed, the G2 checkpoint inhibits the mitosis of cells and ensures the proliferation of error-free genome duplicates to each daughter cell.

\subsection{Galactosidase in situ assay}

The beta galactosidase enzyme activity was used in this work to check the effect of 10-30 and 35-45 nm ZnO NPs on the senescence of BMSCs and AMSCs. Our results showed that the cell areas with positive green staining were observed more frequently at $\mathrm{ZnO}$ NP-treated group in both types of the rat stem cells in comparison with the control group (Fig. 5A, B).

In the normal cells, acid lysosomal $\beta$-galactosidases was produced and collected in the lysosome, as observed in the control groups. But in senescent cells, the lysosome increased and produced an upper level of $\beta$-galactosidase, named senescence-associated $\beta$-galactosidase (SA- $\beta$-gal), as detected in the cells treated with ZnO NPs (Fig. 5). Positive cells of SA- $\beta$ gal were stained blue-green under bright-field microscopy. Both treated cells were positive in comparison to the control groups. The highest blue-green color was obtained in AMSCs with 10-30 nm ZnO NPs (Fig. 5A).

\subsection{Real-time PCR}

Relative expression of NF-kB, P53, and Nanog genes was assessed relative to GAPDH as a housekeeping gene on both BMSCs and AMSCs, which were exposed to 5 and $10 \mu \mathrm{g} / \mathrm{ml}$ ZnO NPs in 10-30 and 35-45 nm sizes, respectively, after $48 \mathrm{~h}$. The results of expression of Nanog genes in the cells treated with 10-30 and 35-45 nm ZnO NPs showed significantly ( $P \leq$ 0.01 ) lower regulation in the AMSCs (Fig. 6A) and BMSCs in comparison with the control group (Fig. 6B).

The cells treated with $10-30 \mathrm{~nm} \mathrm{ZnO}$ NPs showed lower expression of Nanog gene compared with the cells treated with
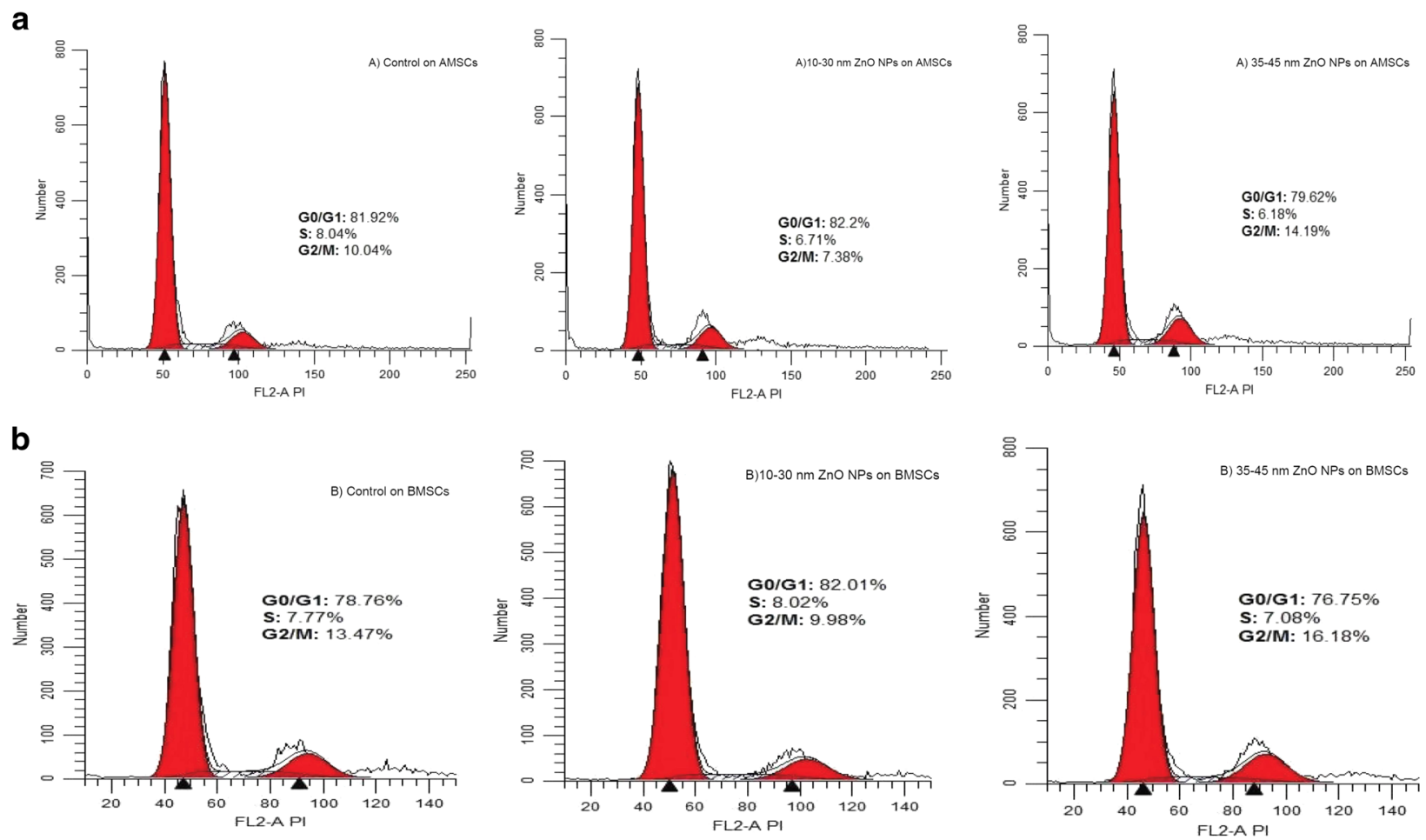

Fig. 4 Cell-cycle analysis following flow cytometry of the cells with 5 and $10 \mu \mathrm{g} / \mathrm{ml}$ transfections for $10-30$ and $35-45 \mathrm{ZnO}$ NPs, respectively. a The AMSCs exposed to 10-30 ZnO NPs represented fewer cells in $\mathrm{G} 2 / \mathrm{M}$ as compared to the control group. b The BMSCs exposed to 10-30 ZnO NPs represented fewer cells in S and G2/M as compared to the control group 
Fig. 5 Senescence-associated$\beta$-galactosidase (SA- $\beta$-gal) staining in the AMSCs and BMSCs. SA- $\beta$-gal-positive cells could be observed more frequently in the treated AMSCs (A) and BMSCs (B) by $\sim 10-30$ and 35-45 ZnO NPs containing 6 and $12 \mu \mathrm{g} / \mathrm{ml}$ concentrations, respectively, in comparison to the control groups

A

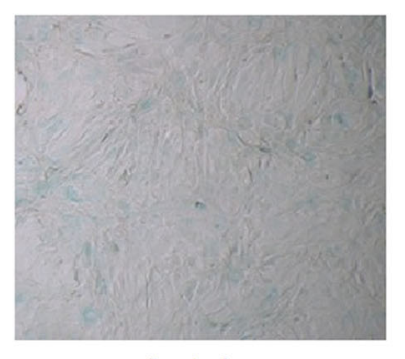

Control

B

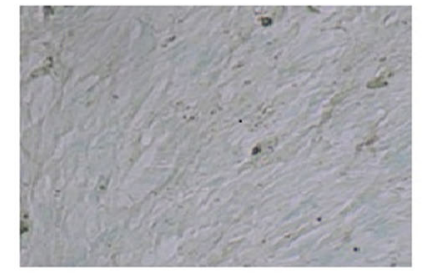

Control

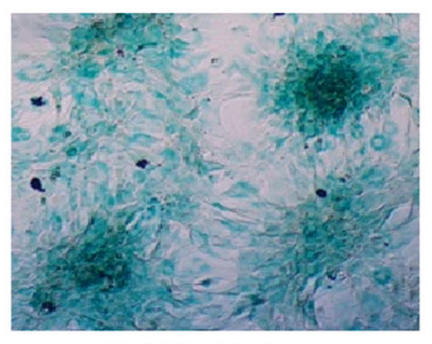

ZnO NPs $10-30 \mathrm{~nm}$

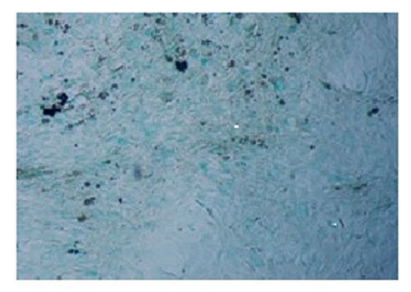

ZnO NPs $10-30$ nm

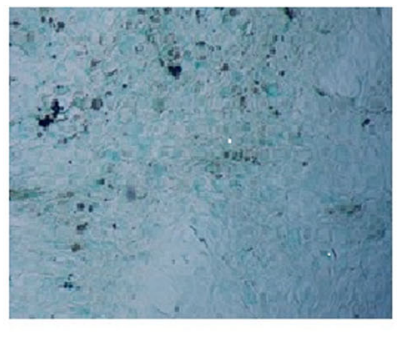

Zno NPs $35-45 \mathrm{~nm}$

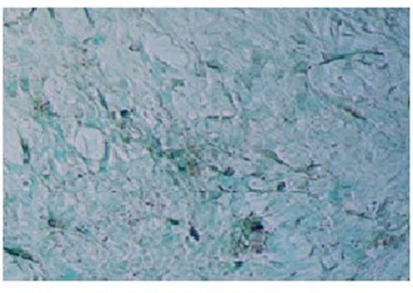

ZnO NPs $35-45 \mathrm{~nm}$
Fig. 6 Relative gene expression of Nanog gene in the cells treated with $\sim 10-30$ and 35-45 of $\mathrm{ZnO}$ NPs in comparison to the control groups. The expression level of the Nanog gene in both AMSCs (A) and BMSCs (B) was significantly downregulated with 10-30 and $\sim 35-45 \mathrm{~nm} Z \mathrm{ZnO}$ NPs $(P \leq 0.001$ and $P \leq 0.01$, respectively). The error bars show mean \pm SD. $* * * P \leq 0.001, * * P \leq 0.01$, and $* P \leq 0.05$
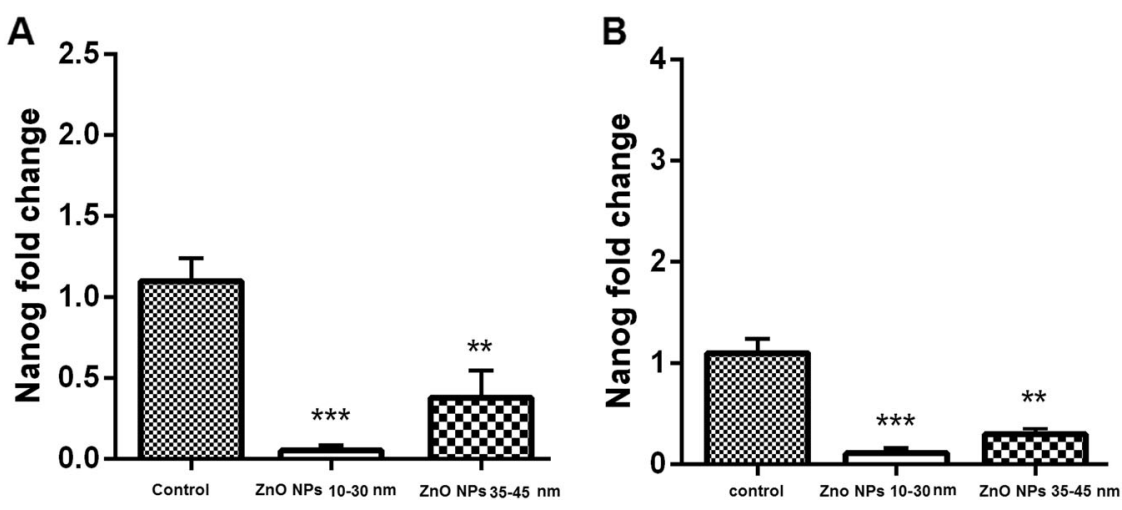

35-45 nm ZnO NPs (Fig. 6). Moreover, the results of expression of NF-kB and P53 genes in AMSCs and BMSCs indicated significant $(P \leq 0.01)$ upregulation compared with the control group (Figs. 7 and 8). As shown in Figs. 6 and 7, the cells treated with $10-30 \mathrm{~nm} \mathrm{ZnO}$ NPs showed higher overexpression than the cells treated with $35-45 \mathrm{~nm} \mathrm{ZnO}$ NPs.

\section{Discussion}

This study evaluated the toxic effects of two sizes of $\mathrm{ZnO}$ NPs on BMSCs and AMSCs; $10-30 \mathrm{~nm}$ as a smaller size and $35-45 \mathrm{~nm}$ as a larger size. The results revealed that the smaller size of $\mathrm{ZnO}$ NPs had a more toxic effect than its larger size. Surface zone and particle size of NPs are significant material qualities from the toxicological point of view. As the particle size reduces, its surface region elevates and permits a higher extent of its particles or atoms to be shown superficially as opposed to the inner side of the material [39].

Nanomaterials smaller than $50 \mathrm{~nm}$ display unique physicochemical properties because of their little size, high surface region, low cost, improved reactivity, and easy entry into the cell dividers [40-42]. According to our MTT assay results, the optimum and safe concentrations of the studied smaller and larger sizes of $\mathrm{ZnO}$ NPs were 5 and $10 \mu \mathrm{g} / \mathrm{ml}$, respectively, in comparison to the control groups. Our cell-cycle analysis showed that safe concentrations of ZnO NPs with $10-30 \mathrm{~nm}$ size have toxic effects on AMSCs by decreasing the number of cells in S and G0/G1 phases, indicating the arrest of the cellcycle process and loss of the signals of drive proliferation. $\mathrm{ZnO}$ NPs in $35-45 \mathrm{~nm}$ size decreased the cells in G2/M and $S$ phases, resulting in the retardation of cell-cycle process.

Our study results are in line with those of other studies that have shown that NPs may lead to death of the cell by means of harming DNA or organelles [43, 44]. Although 


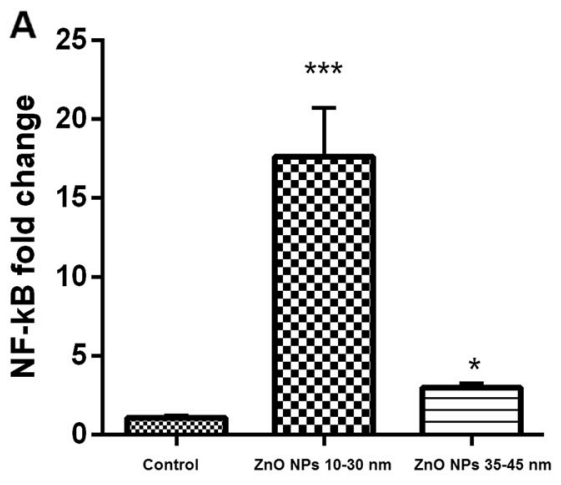

Fig. 7 Relative gene expression of NF-kB gene in the cells treated with 10-30 and 35-45 of ZnO NPs in comparison to the control groups. The expression level of the NF-kB gene in both AMSCs (A) and

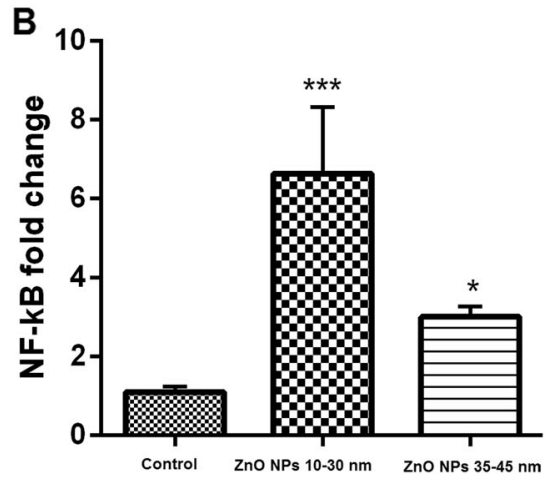

BMSCs (B) with $\sim 10-30$ and 35-45 ZnO NPs was significantly upregulated ( $P \leq 0.05$ and $P \leq 0.001$, respectively). The error bars show mean \pm SD. $* * * P \leq 0.001, * * P \leq 0.01$, and $* P \leq 0.05$
Fig. 8 Relative gene expression of the P53 gene in the cells treated with $\sim 10-30$ and 35-45 $\mathrm{ZnO}$ NPs in comparison to the control groups. The expression level of P53 gene in both AMSCs (A) and BMSCs (B) with $\sim 10-30$ and $35-45 \mathrm{ZnO}$ NPs was significantly upregulated $(P \leq 0.001$ and $P \leq 0.01$, respectively). The error bars show mean $\pm \mathrm{SD}$. $* * * P \leq$ 0.001 , $* * P \leq 0.01$, and $* P \leq 0.05$

Fig. 9 Schematic of ZnO NPs interaction in the mammalian cell. $\mathrm{ZnO}$ nanoparticles complex with the water generated $\mathrm{Zn}^{2+}$ ions. These ions are insoluble by the cell and generate reactive oxygen species (ROS). ROS resulted in cell inflammation by inducing cytokines and also caused mitochondrion phosphorylation dysfunction and lysosomal destabilization. Finally, ROS caused cellular dysfunction and cell death [10-13]. ZnO NPs influenced genotoxicity and oxidative DNA damage $[50,51]$
A
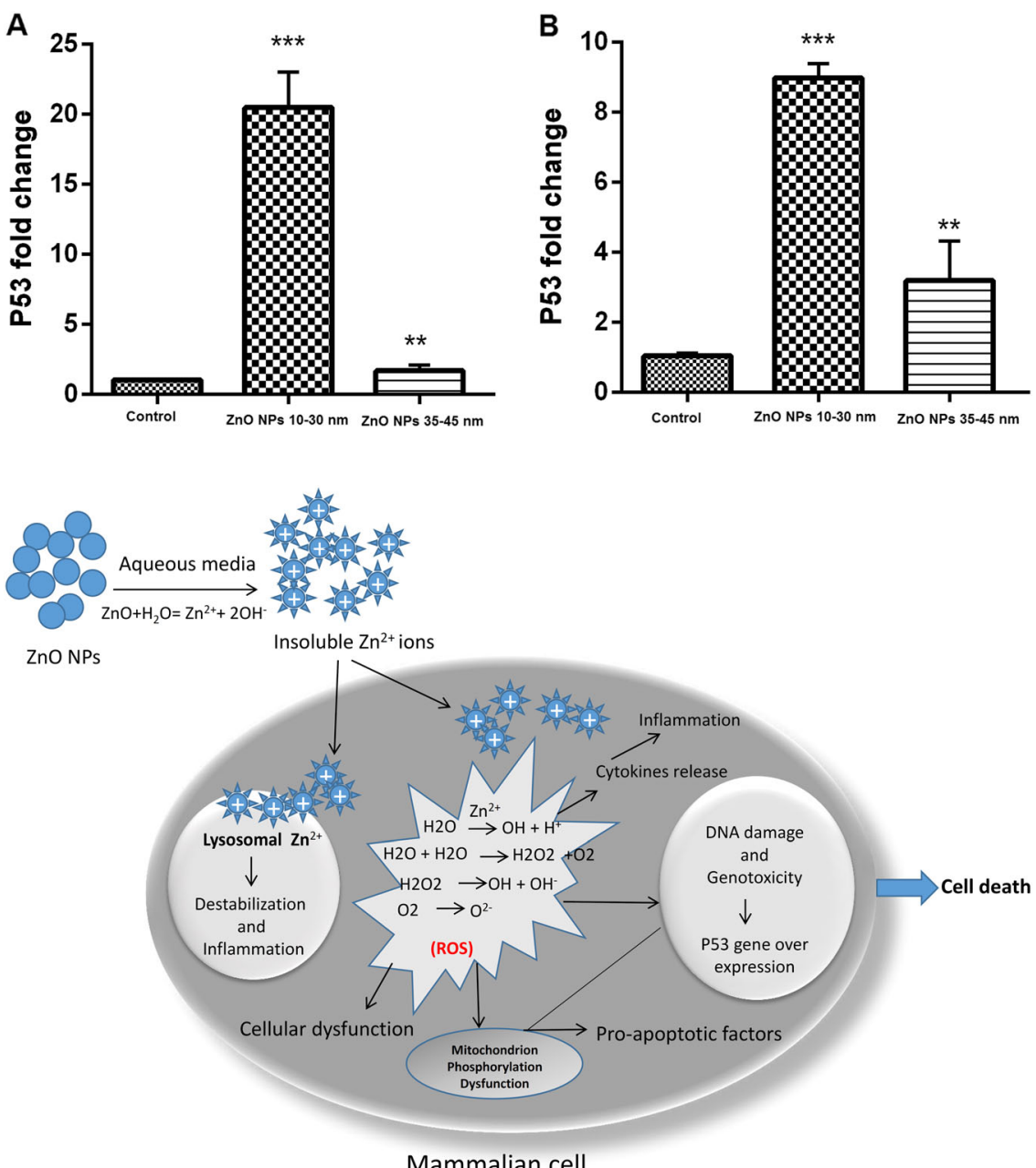

there are limited toxicological reports of $\mathrm{ZnO}$ NPs impact, there are a few reports on $\mathrm{ZnO}$ NPs cytotoxic effects in vitro [45-47]. A study showed that oxidative stress was activated in TR146 cells with $10 \mu \mathrm{g} / \mathrm{ml}$ concentration of ZnO NPs [48] and in SH-SY5Y cells with $15 \mu \mathrm{g} / \mathrm{ml}$ concentration [49]. A pro-inflammatory cytokine released in THP-1 cells with $17.69 \mu \mathrm{g} / \mathrm{ml}$ of $\mathrm{ZnO}$ NPs [20]. DNA damage was also made at $6.4 \mu \mathrm{g} / \mathrm{ml}$ concentration of $\mathrm{ZnO} \mathrm{NPs}$ in human colon carcinoma cells [50] and at $12.5 \mu \mathrm{g} / \mathrm{ml}$ concentration in epithelial cells of rat kidney [51]. Contact to nanomaterials is unavoidable because they are becoming a part of our everyday life; accordingly, the toxicity of nanomaterials 
research is taken into consideration [52]. Figure 9 illustrates the interaction of $\mathrm{ZnO}$ NPs in the mammalian cell. The determination of senescent cells showed increased lysosomal $\beta$-galactosidase activity level [53]. Our SA- $\beta$-gal test results showed that $\mathrm{ZnO}$ NPs in both smaller and larger sizes (10-30 and 35-45 $\mathrm{nm}$ ) stimulated the cells to produce the lysosome. However, a high blue-green color was induced by high lysosomal levels in the cells exposed with 10-30 nm of ZnO NPs in compared with the control group.

P53 works as a lifespan quality of excellence of its strong tumor silencer activity and an aging controller [54]. p53 can decrease and increase oxidative stress possibly due to its double effect on senescence. Our real-time PCR results indicated a significant upregulated expression of p53 and NF-kB genes in the cells exposed to both sizes of ZnO NPs. However, the highest overexpression of these genes was detected in the cells treated with a smaller size $(10-30 \mathrm{~nm})$ of NPs. Moreover, the mRNA level of Nanog gene was considered as an anti-aging gene. For Nanog gene, the results of our study showed a significant downregulation of both studied sizes of $\mathrm{ZnO}$ NPs in both treated cells. However, the lowest downregulation in the $10-30 \mathrm{~nm}$ size indicated that $\mathrm{ZnO}$ NPs can be more toxic in the smaller size than in the larger size $(35-45 \mathrm{~nm})$.

\section{Conclusion}

ZnO NPs (10-30 and 35-45 $\mathrm{nm}$ ) prompt the cells to aging process. The smaller size of $\mathrm{ZnO}$ NPs has more toxic effects on DNA synthesis than the larger size. The highest $\beta$-galactosidase staining was observed in the smaller size than the larger size of ZnO NPs. In addition, a significant overexpression of aging-related genes (NF-kB and p53) was acquired in $\mathrm{ZnO}$ NPs cells treated with both sizes. Furthermore, a significant downregulation of anti-aging-related gene (Nanog) was acquired in the cells treated with ZnO NPs.

Acknowledgements The authors are thankful to the Faculty of Veterinary Medicine, University of Tabriz and Research Affairs of Tabriz University of Medical Sciences, Faculty of Advanced Medical Sciences.

Funding This work was granted by University of Tabriz.

\section{Compliance with ethical standards}

Conflict of interest The authors declare no competing interests.

Ethics approval The ethical standards of the Faculty of Veterinary Medicine are approved with Protocol No. FVM.REC.1395.939 and those of the Medical Sciences Ethical Committee are confirmed with No. $5 / \mathrm{d} / 90471$.

Publisher's note Springer Nature remains neutral with regard to jurisdictional claims in published maps and institutional affiliations.
Open Access This article is licensed under a Creative Commons Attribution 4.0 International License, which permits use, sharing, adaptation, distribution and reproduction in any medium or format, as long as you give appropriate credit to the original author(s) and the source, provide a link to the Creative Commons license, and indicate if changes were made. The images or other third party material in this article are included in the article's Creative Commons license, unless indicated otherwise in a credit line to the material. If material is not included in the article's Creative Commons license and your intended use is not permitted by statutory regulation or exceeds the permitted use, you will need to obtain permission directly from the copyright holder. To view a copy of this license, visit http://creativecommons. org/licenses/by/4.0/.

\section{References}

1. De Angelis I, Barone F, Zijno A, Bizzarri L, Russo MT, Pozzi R, et al. Comparative study of $\mathrm{ZnO}$ and $\mathrm{TiO} 2$ nanoparticles: physicochemical characterisation and toxicological effects on human colon carcinoma cells. Nanotoxicology. 2013;7:1361-72.

2. Ma H, Williams PL, Diamond SA. Ecotoxicity of manufactured ZnO nanoparticles-a review. Environ Pollut. 2013;172:76-85.

3. Teow Y, Asharani P, Hande MP, Valiyaveettil S. Health impact and safety of engineered nanomaterials. Chem Commun. 2011;47:7025-38.

4. Liu W-T. Nanoparticles and their biological and environmental applications. J Biosci Bioeng. 2006;102:1-7.

5. Xiong $\mathrm{HM}$. $\mathrm{ZnO}$ nanoparticles applied to bioimaging and drug delivery. Adv Mater. 2013;25:5329-35.

6. Wang J, Sun XW, Wei A, Lei Y, Cai X, Li CM, et al. Zinc oxide nanocomb biosensor for glucose detection. Appl Phys Lett. 2006;88:233106.

7. Serpone N, Dondi D, Albini A. Inorganic and organic UV filters: Their role and efficacy in sunscreens and suncare products. Inorg Chim Acta. 2007;360:794-802.

8. Dastjerdi R, Montazer M. A review on the application of inorganic nano-structured materials in the modification of textiles: focus on anti-microbial properties. Colloids Surf B: Biointerfaces. 2010;79:5-18.

9. Huang Z, Zheng X, Yan D, Yin G, Liao X, Kang Y, et al. Toxicological effect of $\mathrm{ZnO}$ nanoparticles based on bacteria. Langmuir. 2008;24:4140-4.

10. Ivask A, Juganson K, Bondarenko O, Mortimer M, Aruoja V, Kasemets $\mathrm{K}$, et al. Mechanisms of toxic action of $\mathrm{Ag}, \mathrm{ZnO}$ and $\mathrm{CuO}$ nanoparticles to selected ecotoxicological test organisms and mammalian cells in vitro: a comparative review. Nanotoxicology. 2014;8:57-71.

11. Xia T, Kovochich M, Brant J, Sempf J, Sioutas C, Yeh JI, et al. Comparison of the abilities of ambient and manufactured nanoparticles to induce cellular toxicity according to an oxidative stress paradigm. Nano Lett. 2006;6:1794-807.

12. Li M, Zhu L, Lin D. Toxicity of $\mathrm{ZnO}$ nanoparticles to Escherichia coli: mechanism and the influence of medium components. Environ Sci Technol. 2011;45:1977-83.

13. Landsiedel R, Ma-Hock L, Kroll A, Hahn D, Schnekenburger J, Wiench $\mathrm{K}$, et al. Testing metal-oxide nanomaterials for human safety. Adv Mater. 2010;22:2601-27.

14. Han X, Geller B, Moniz K, Das P, Chippindale AK, Walker VK. Monitoring the developmental impact of copper and silver nanoparticle exposure in Drosophila and their microbiomes. Sci Total Environ. 2014;487:822-9.

15. Ates M, Arslan Z, Demir V, Daniels J, Farah IO. Accumulation and toxicity of $\mathrm{CuO}$ and $\mathrm{ZnO}$ nanoparticles through waterborne 
and dietary exposure of goldfish (Carassius auratus). Environ Toxicol. 2015;30:119-28.

16. Hanna SK, Miller RJ, Zhou D, Keller AA, Lenihan HS. Accumulation and toxicity of metal oxide nanoparticles in a softsediment estuarine amphipod. Aquat Toxicol. 2013;142:441-6.

17. Chien C-C, Yan Y-H, Juan H-T, Cheng T-J, Liao J-B, Lee H-P, et al. Sustained renal inflammation following 2 weeks of inhalation of occupationally relevant levels of zinc oxide nanoparticles in Sprague Dawley rats. J Toxicol Pathol. 2017;30:307-14.

18. Amara S, Slama IB, Mrad I, Rihane N, Khemissi W, El Mir L, et al. Effects of zinc oxide nanoparticles and/or zinc chloride on biochemical parameters and mineral levels in rat liver and kidney. Hum Exp Toxicol. 2014;33:1150-7.

19. Rousk J, Ackermann K, Curling SF, Jones DL. Comparative toxicity of nanoparticulate $\mathrm{CuO}$ and $\mathrm{ZnO}$ to soil bacterial communities. PloS One. 2012;7:e34197.

20. Sahu D, Kannan G, Vijayaraghavan R. Size-dependent effect of zinc oxide on toxicity and inflammatory potential of human monocytes. J Toxicol Environ Health Part A. 2014;77:177-91.

21. Chang Y-N, Zhang M, Xia L, Zhang J, Xing G. The toxic effects and mechanisms of $\mathrm{CuO}$ and $\mathrm{ZnO}$ nanoparticles. Materials. 2012;5:2850-71.

22. Akhtar MJ, Ahamed M, Kumar S, Khan MM, Ahmad J, Alrokayan SA. Zinc oxide nanoparticles selectively induce apoptosis in human cancer cells through reactive oxygen species. Int $\mathbf{J}$ Nanomed. 2012;7:845.

23. Sruthi S, Ashtami J, Mohanan PV. Biomedical application and hidden toxicity of Zinc oxide nanoparticles. Mater Today Chem. 2018;10:175-86.

24. Stephen L, Chris SP, Carrie AD, Parveen S, Kevin Park B, Goldring CEP. Stem cell models as an in vitro model for predictive toxicology. Biochem J. 2019;476:1149-58.

25. Ben-Ishay Z, Barak V. Bone marrow stromal dysfunction in mice administered cytosine arabinoside. Eur J Haematol. 2001;66:230-7.

26. Kang KS, Trosko JE. Stem cells in toxicology: fundamental biology and practical considerations. Toxicological Sci. 2011;120: S269-89.

27. Peijia Y, Qing N, Chao T, Lei Z. Nanog induced intermediate state in regulating stem cell differentiation and reprogramming. BMC Syst Biol. 2018;12:22.

28. Münst B, Thier MC, Winnemöller D, Helfen M, Thummer RP, Edenhofer F. Nanog induces suppression of senescence through downregulation of p27 ${ }^{\mathrm{KIP} 1}$ expression. J Cell Sci. 2016;129:912-20.

29. Magalhães DJP, Curado J, Church GM. Meta-analysis of agerelated gene expression profiles identifies common signatures of aging. Bioinformatics. 2009;25:875-81.

30. Alhadlaq A, Mao JJ. Mesenchymal stem cells: isolation and therapeutics. Stem Cells Dev. 2004;13:436-48.

31. Kingham PJ, Kalbermatten DF, Mahay D, Armstrong SJ, Wiberg M, Terenghi G. Adipose-derived stem cells differentiate into a Schwann cell phenotype and promote neurite outgrowth in vitro. Exp Neurol. 2007;207:267-74.

32. Chen D, Tang Q, Li X, Zhou X, Zang J, Xue W-Q, et al. Biocompatibility of magnetic $\mathrm{Fe} 3 \mathrm{O} 4$ nanoparticles and their cytotoxic effect on MCF-7 cells. Int J Nanomed. 2012;7:4973.

33. Alizadeh E, Akbarzadeh A, Eslaminejad MB, Barzegar A, Hashemzadeh S, Nejati-Koshki K, et al. Up regulation of liverenriched transcription factors HNF 4a and HNF 6 and liver-specific Micro RNA (miR-122) by inhibition of Let-7b in mesenchymal stem cells. Chem Biol Drug Des. 2015;85:268-79.

34. Crisan M, Yap S, Casteilla L, Chen C-W, Corselli M, Park TS, et al. A perivascular origin for mesenchymal stem cells in multiple human organs. Cell Stem Cell. 2008;3:301-13.
35. Gerloff K, Albrecht C, Boots AW, Förster I, Schins RP. Cytotoxicity and oxidative DNA damage by nanoparticles in human intestinal Caco-2 cells. Nanotoxicology. 2009;3:355-64.

36. Wahab R, Dwivedi S, Umar A, Singh S, Hwang I, Shin H-S, et al. $\mathrm{ZnO}$ nanoparticles induce oxidative stress in Cloudman S91 melanoma cancer cells. J Biomed Nanotechnol. 2013;9:441-9.

37. Dimri GP, Lee X, Basile G, Acosta M, Scott G, Roskelley C, et al. A biomarker that identifies senescent human cells in culture and in aging skin in vivo. Proc Natl Acad Sci USA. 2007;92:9363-7.

38. White J, Dalton S. Cell cycle control of embryonic stem cells. Stem Cell Rev. 2005;1:131-8.

39. Nel A, Xia T, Mädler L, Li N. Toxic potential of materials at the nanolevel. Science. 2006;311:622-7.

40. Yan S, Shi Y, Xiao Z, Zhou M, Yan W, Shen H, et al. Development of biosensors based on the one-dimensional semiconductor nanomaterials. J Nanosci Nanotechnol. 2012;12:6873-9.

41. Iannazzo D, Piperno A, Romeo G, Romeo R, Ferlazzo A, Pistone A, et al. Coumarin-conjugated multiwalled carbon nanotubes for potential biological applications: development and characterization. J Nanosci Nanotechnol. 2012;12:5030-8.

42. Singh S. Nanomedicine-nanoscale drugs and delivery systems. J Nanosci Nanotechnol. 2010;10:7906-18.

43. Manke A, Wang L, Rojanasakul Y. Mechanisms of nanoparticle-induced oxidative stress and toxicity. Biomed Res Int. 2013;2013:942916.

44. Buzea C, Pacheco II, Robbie K. Nanomaterials and nanoparticles: sources and toxicity. Biointerphases. 2007;2:MR17-71.

45. Xia T, Kovochich M, Liong M, Madler L, Gilbert B, Shi H, et al. Comparison of the mechanism of toxicity of zinc oxide and cerium oxide nanoparticles based on dissolution and oxidative stress properties. ACS Nano. 2008;2:2121-34.

46. Yuan J-H, Chen Y, Zha H-X, Song L-J, Li C-Y, Li J-Q, et al. Determination, characterization and cytotoxicity on HELF cells of $\mathrm{ZnO}$ nanoparticles. Colloids Surf B: Biointerfaces. 2010; 76:145-50.

47. Heng BC, Zhao X, Xiong S, Ng KW, Boey FY-C, Loo JS-C. Toxicity of zinc oxide $(\mathrm{ZnO})$ nanoparticles on human bronchial epithelial cells (BEAS-2B) is accentuated by oxidative stress. Food Chem Toxicol. 2010;48:1762-6.

48. Giovanni M, Tay CY, Setyawati MI, Xie J, Ong CN, Fan R, et al. Toxicity profiling of water contextual zinc oxide, silver, and titanium dioxide nanoparticles in human oral and gastrointestinal cell systems. Environ Toxicol. 2015;30:1459-69.

49. Taccola L, Raffa V, Riggio C, Vittorio O, Iorio MC, Vanacore R, et al. Zinc oxide nanoparticles as selective killers of proliferating cells. Int J Nanomed. 2011;6:1129.

50. Zijno A, De Angelis I, De Berardis B, Andreoli C, Russo MT, Pietraforte D, et al. Different mechanisms are involved in oxidative DNA damage and genotoxicity induction by $\mathrm{ZnO}$ and $\mathrm{TiO} 2$ nanoparticles in human colon carcinoma cells. Toxicol Vitr. 2015;29:1503-12.

51. Uzar NK, Abudayyak M, Akcay N, Algun G, Özhan G. Zinc oxide nanoparticles induced cyto-and genotoxicity in kidney epithelial cells. Toxicol Mech Methods. 2015;25:334-9.

52. Liu Q, Xu C, Ji G, Liu H, Mo Y, Tollerud DJ, et al. Sublethal effects of zinc oxide nanoparticles on male reproductive cells. Toxicol Vitr. 2016;35:131-8.

53. Kurz DJ, Decary S, Hong Y, Erusalimsky JD. Senescenceassociated (Beta)-galactosidase reflects an increase in lysosomal mass during replicative ageing of human endothelial cells. J cell Sci. 2000;113:3613-22.

54. Vigneron A, Vousden KH. p53, ROS and senescence in the control of aging. Aging (Albany NY). 2010;2:471. 